\title{
molecules
}

ISSN 1420-3049

www.mdpi.com/journal/molecules

Article

\section{A New Cytotoxic Pregnanone from Calotropis gigantea}

\section{Zhu-Nian Wang ${ }^{1, *}$, Mao-Y uan Wang ${ }^{1}$, Wen-L i Mei ${ }^{2}$, Zhuang Han ${ }^{2}$ and Hao-Fu Dai ${ }^{1,2, *}$}

1 Institute of Crops Genetic Resources, Chinese Academy of Tropical Agricultural Sciences, Danzhou, 571737, P. R. China; E-mails:wmy81@163.com (M-Y. W.); wangzhunian@yahoo.com.cn (Z-N.W.)

2 Institute of Tropical Bioscience and Biotechnology, Chinese Academy of Tropical Agricultural Sciences, Haikou, 571101, P. R. China; E-mails: hanzone@yahoo.cn (Z. H.); meiwenli@yahoo.com.cn (W-L. M.)

* Author to whom correspondence should be addressed; E-mail: hfdai@yahoo.cn; Tel: +86-898-6698-8061; Fax: +86-898-6698-8061.

Received: 25 September 2008; in revised form: 26 November 2008 / Accepted: 3 December 2008 / Published: 4 December 2008

\begin{abstract}
A new pregnanone, named calotropone (1), was isolated from the EtOH extract of the roots of Calotropis gigantea L. together with a known cardiac glycoside. The structures were elucidated by a study of their physical and spectral data. Compounds $\mathbf{1}$ and 2 displayed inhibitory effects towards chronic myelogenous leukemia K562 and human gastric cancer SGC-7901 cell lines.
\end{abstract}

Keywords: Calotropis gigantea L.; Calotropone; Cytotoxicity.

\section{Introduction}

The genus Calotropis (Asclepiadaceae) is comprised of about six species of shrubs distributed throughout tropical and subtropical Africa and Asia. Two of them, Calotropis gigantea L. and Calotropis procera L. occur in China, and are two sister species. C. gigantea is a high biomass, fast growing perennial shrub growing as a weed in the Hainan province of China [1]. It was used as a traditional folk medicine for the treatment of anthelmintic, carminative, cough, leprosy, and asthma by the people of the Li nationality, who are autochthonous to Hainan island in China. The chemical 
constituents of $C$. gigantea have been extensively investigated, leading to the isolation of many cardenolides [2-5], flavonoids [6], terpenes [7-10], pregnanes [11-12] and a nonprotein amino acid [13]. During our screening for cytotoxic agents from tropical medicinal plants, the ethanol extract of the roots of $C$. gigantea showed cytotoxic activity towards human chronic myelogenous leukemia (K562) and human gastric cancer (SGC-7901) cell lines in vitro by MTT method with $\mathrm{IC}_{50}$ values of 9.7 $\mu \mathrm{g} / \mathrm{mL}$ and $6.7 \mu \mathrm{g} / \mathrm{mL}$, respectively. Bioassay-guided fractionation led to the isolation of a new pregnanone, calotropone, together with one known cardiac glycoside gofruside (2) from the ethanol extract of $C$. gigantea, their structures were elucidated using spectral means especially $1 \mathrm{D}$ and 2D NMR spectroscopy. Both compounds 1 and 2 showed significant cytotoxicity against K562 and SGC7901 cell lines. In this paper, we describe the isolation, structural elucidation, and cytotoxicity of $\mathbf{1}$ and 2.

Figure 1. Structures of Compounds 1 and 2.

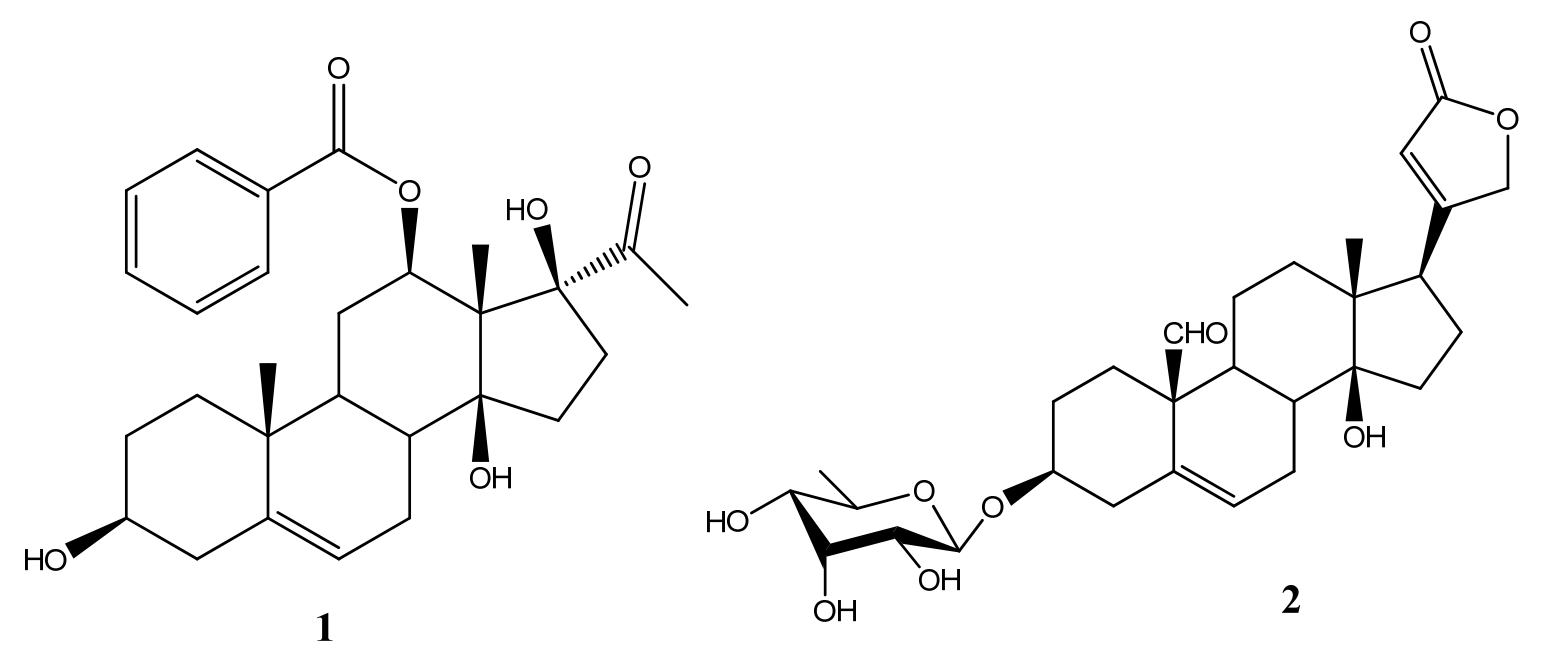

\section{Results and Discussion}

Bioassay-guided fractionation of the ethanol extract of $C$. gigantea led to the isolation of compounds 1 and 2. Compound 1 was obtained as yellow gum. The $[\mathrm{M}+\mathrm{Na}]^{+}$at $\mathrm{m} / z$ 491.2409 (calcd 491.2404) in the high-resolution ESI-Mass spectrum corresponded to the molecular formula $\mathrm{C}_{28} \mathrm{H}_{36} \mathrm{O}_{6}$. This formula can also be validated through ${ }^{1} \mathrm{H}-\mathrm{NMR},{ }^{13} \mathrm{C}-\mathrm{NMR}$ and DEPT spectra. The IR spectrum of 1 showed absorption bands due to a hydroxyl $\left(3,431 \mathrm{~cm}^{-1}\right)$ and a carbonyl $\left(1,712 \mathrm{~cm}^{-1}\right)$ group, whereas the UV spectrum of 1 suggested the presence of a benzoyl group (absorption maxima at 241, 267, and $284 \mathrm{~nm}$ ). The ${ }^{1} \mathrm{H}-\mathrm{NMR}$ spectrum of 1 suggested the presence of a benzoyl group [signals at $\delta 7.43$ $(2 \mathrm{H}, \mathrm{t}, J=7.5 \mathrm{~Hz}), 7.56(1 \mathrm{H}, \mathrm{t}, J=7.5 \mathrm{~Hz}), 7.93(2 \mathrm{H}, \mathrm{d}, J=7.5 \mathrm{~Hz})]$. In addition, one olefinic proton $(\delta 5.41, \mathrm{~m})$ and three high field methyl singlet at $\delta 2.06,1.41$, and 0.98 were also observed. The ${ }^{13} \mathrm{C}$ NMR (DEPT) spectra of 1 showed the coexistence of three methyl groups, seven methylene groups, two aliphatic $\mathrm{sp}^{3}$ methine carbons, two oxygenated $\mathrm{sp}^{3}$ methine carbons, four $\mathrm{sp}^{3}$ quaternary carbon atoms, one tri-substituted double bond, one benzoyl group, and one ketone. This observation suggested that 1 was likely to be a lineolon-type compound. Comparing the ${ }^{13} \mathrm{C}-\mathrm{NMR}$ spectral data with those of the 12-O-benzoyllineolon showed that $\mathbf{1}$ had one tertiary carbon more and one quarternary carbon less than 12-O-benzoyllineolon [12]. The ${ }^{1} \mathrm{H}-{ }^{1} \mathrm{H}$ COSY, HMQC, and HMBC spectra allowed the complete 
assignments of chemical shifts of $\mathbf{1}$ (Table 1). The chemical shift of C-8 of $\mathbf{1}$ was upfield shifted to $\delta$ 37.0, which suggested that C-8 was not substituted by a hydroxyl group as $12-O$-benzoyllineolon. The relative stereochemistry of $\mathbf{1}$ was determined by ROESY correlations (Figure 2). Based on the above evidence, the structure of compound 1 was identified as $12 \beta$ - $O$-benzoyl-3 $\beta, 14 \beta, 17 \beta$-trihydroxypregnane-20-one, named calotropone.

Figure 2. Key HMBC and ROESY correlations of compound 1.
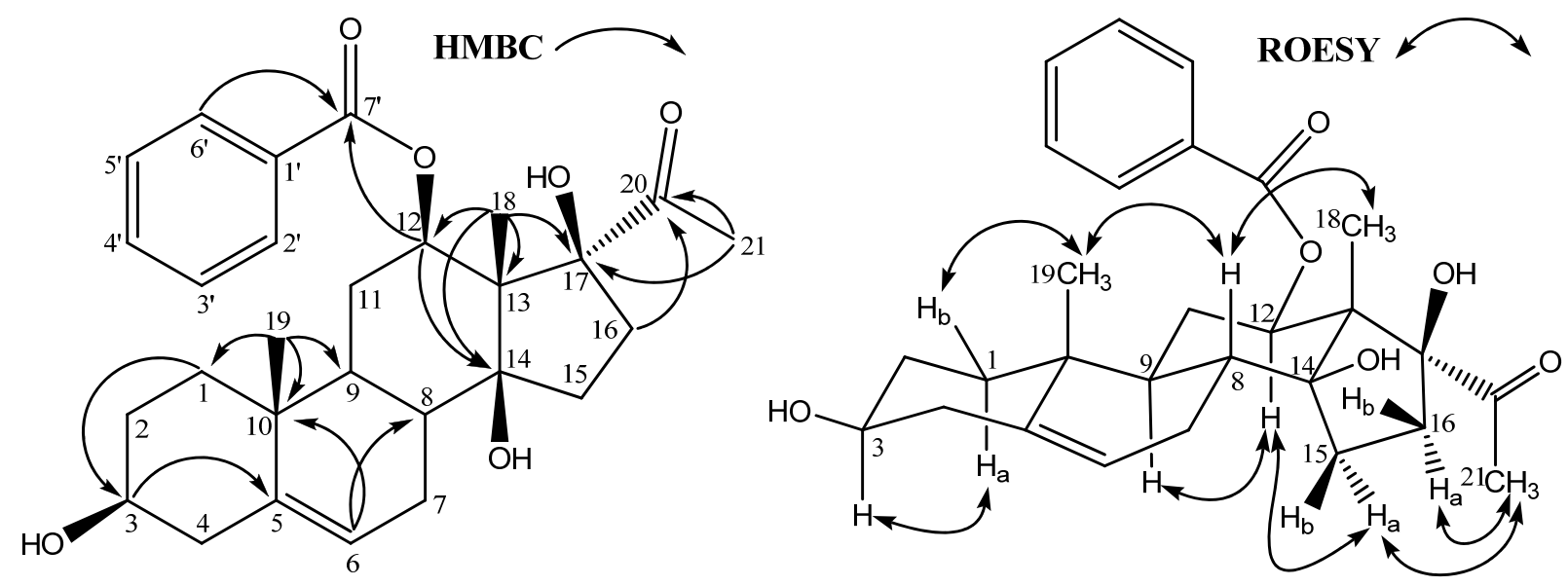

Compounds 1 and 2 were evaluated for their cytotoxic activity against K562 and SGC-7901 cell lines using the MTT method [14], and both of them showed significant cytotoxicity against the two cell lines (Table 2).

Table 1. The NMR data of compound 1.

\begin{tabular}{llll}
\hline Position & $\boldsymbol{\delta}_{\mathbf{C}}$ & $\boldsymbol{\delta}_{\mathbf{H}}$ & HMBC \\
\hline $\mathbf{1}$ & 37.0 & $1.75(1 \mathrm{H}, \mathrm{m}, \mathrm{H}-1 \mathrm{a}), 1.13(1 \mathrm{H}, \mathrm{m}, \mathrm{H}-1 \mathrm{~b})$ & $\mathrm{C}-2,3,5,10$ \\
$\mathbf{2}$ & 31.4 & $1.81,1.46($ each $1 \mathrm{H}, \mathrm{m})$ & $\mathrm{C}-3,4,10$ \\
$\mathbf{3}$ & 71.4 & $3.53(1 \mathrm{H}, \mathrm{m})$ & $\mathrm{C}-1,2,5$ \\
$\mathbf{4}$ & 41.9 & $2.33(1 \mathrm{H}, \mathrm{dd}, 12.8,3.6 \mathrm{~Hz}), 2.25(1 \mathrm{H}, \mathrm{m}$, overlapped $)$ & $\mathrm{C}-2,6,5,10$ \\
$\mathbf{5}$ & 139.5 & & \\
$\mathbf{6}$ & 121.1 & $5.41(1 \mathrm{H}, \mathrm{m})$ & $\mathrm{C}-4,5,7,10$ \\
$\mathbf{7}$ & 26.0 & $2.20,1.91(\mathrm{each} 1 \mathrm{H}, \mathrm{m})$ & $\mathrm{C}-5,6,9,14$ \\
$\mathbf{8}$ & 37.0 & $1.80(1 \mathrm{H}, \mathrm{m})$ & $\mathrm{C}-7,10,14$ \\
$\mathbf{9}$ & 42.6 & $1.32(1 \mathrm{H}, \mathrm{m})$ & $\mathrm{C}-1,5,11,12,14$ \\
$\mathbf{1 0}$ & 36.7 & & $\mathrm{C}-8,10,13$ \\
$\mathbf{1 1}$ & 26.5 & $2.06,1.45(\mathrm{each} 1 \mathrm{H}, \mathrm{m}, \mathrm{overlapped})$ & $\mathrm{C}-9,14,17,19,7^{\prime}$ \\
$\mathbf{1 2}$ & 73.1 & $4.80(1 \mathrm{H}, \mathrm{dd}, 11.3,4.5 \mathrm{~Hz})$ & \\
$\mathbf{1 3}$ & 57.5 & & $\mathrm{C}-8,13,17$ \\
$\mathbf{1 4}$ & 88.5 & & \\
$\mathbf{1 5}$ & 31.7 & $2.12(1 \mathrm{H}, \mathrm{m}, \mathrm{H}-15 \mathrm{a}), 1.92(1 \mathrm{H}, \mathrm{m}, \mathrm{H}-15 \mathrm{~b})$ & \\
\hline
\end{tabular}


Table 1. Cont.

\begin{tabular}{llll}
\hline $\mathbf{1 6}$ & 31.8 & $2.90(1 \mathrm{H}, \mathrm{m}, \mathrm{H}-16 \mathrm{a}), 1.88(1 \mathrm{H}, \mathrm{m}, \mathrm{H}-16 \mathrm{~b})$ & $\mathrm{C}-13,14,20$ \\
$\mathbf{1 7}$ & 91.2 & & \\
$\mathbf{1 8}$ & 7.7 & $1.41(3 \mathrm{H}, \mathrm{s})$ & $\mathrm{C}-12,13,14,17$ \\
$\mathbf{1 9}$ & 19.4 & $0.98(3 \mathrm{H}, \mathrm{s})$ & $\mathrm{C}-1,5,9,10$ \\
$\mathbf{2 0}$ & 209.3 & & \\
$\mathbf{2 1}$ & 27.4 & $2.06(3 \mathrm{H}$, overlapped $)$ & $\mathrm{C}-17,20$ \\
$\mathbf{1}^{\prime}$ & 129.9 & & \\
$\mathbf{2}^{\prime}$ & 128.4 & $7.93(1 \mathrm{H}, \mathrm{d}, 7.5 \mathrm{~Hz})$ & $\mathrm{C}-1^{\prime}, 3^{\prime}, 4^{\prime}, 6^{\prime}$ \\
$\mathbf{3}^{\prime}$ & 129.5 & $7.43(1 \mathrm{H}, \mathrm{t}, 7.5 \mathrm{~Hz})$ & $\mathrm{C}-1^{\prime}, 2^{\prime}, 4^{\prime}, 5^{\prime}$ \\
$\mathbf{4}^{\prime}$ & 133.2 & $7.56(1 \mathrm{H}, \mathrm{t}, 7.5 \mathrm{~Hz})$ & $\mathrm{C}-2^{\prime}, 3^{\prime}, 5^{\prime}, 6^{\prime}$ \\
$\mathbf{5}^{\prime}$ & 129.5 & $7.43(1 \mathrm{H}, \mathrm{t}, 7.5 \mathrm{~Hz})$ & $\mathrm{C}-1^{\prime}, 3^{\prime}, 4^{\prime}, 6^{\prime}$ \\
$\mathbf{6}^{\prime}$ & 128.4 & $7.93(1 \mathrm{H}, \mathrm{d}, 7.5 \mathrm{~Hz})$ & $\mathrm{C}-1^{\prime}, 2^{\prime}, 4^{\prime}, 5^{\prime}, 7^{\prime}$ \\
$\mathbf{7}^{\prime}$ & 165.3 & & \\
\hline
\end{tabular}

The data were measured in $\mathrm{CDCl}_{3}$ with reference to TMS.

Table 2. $\mathrm{IC}_{50}$ values for inhibition of human cell lines of compounds $\mathbf{1}$ and $\mathbf{2}$.

\begin{tabular}{lccc}
\hline & \multicolumn{3}{c}{ Compounds $\left(\mathrm{IC}_{50, \mu \mathrm{g} / \mathrm{mL})}\right.$} \\
\cline { 2 - 4 } Cell lines & $\mathbf{1}$ & $\mathbf{2}$ & Mitomycin C $^{*}$ \\
\hline K562 & 9.2 & 4.7 & 7.1 \\
SGC-7901 & 91.3 & 14.1 & 8.8 \\
\hline
\end{tabular}

${ }^{*}$ Mitomycin C (MMC) was used as a positive control.

\section{Conclusions}

Although $C$. gigantea was used as a very famous traditional folk medicine by many cultures, and it has been the subject of extensive phytochemical and bioactive investigations, its chemical components and bioactivities have not been completely investigated yet. Up to now, seven oxypregnaneoligoglycosides, calotroposides $\mathrm{A}-\mathrm{G}$ have been isolated from the roots of $C$. gigantea $[5,11]$. In our present study a new pregnanone was isolated and identified from the genus of Calotropis, this is the first steroidal aglycone isolated from this genus. Meanwhile, the cytotoxicity against K562 and SGC7901 cell lines of compounds $\mathbf{1}$ and $\mathbf{2}$ was evaluated for the first time, this is also the first report about the cytotoxicity of the pregnanone from this genus.

\section{Experimental}

\section{General}

Melting points were obtained on Beijing Taike X-5 stage apparatus uncorrected. The NMR spectra were recorded on Bruker AV-400 spectrometer, using TMS as an internal standard. The FAB-MS 
spectra were measured with a VG Autospec-3000 mass spectrometer, and the HRESI-MS spectra were measured with an API QSTAR Pulsar mass spectrometer. The IR spectra were obtained on a Nicolet 380 FT-IR instrument, as $\mathrm{KBr}$ pellets. The UV spectra were measured on a Beckman DU800 spectrometer. Optical rotation was recorded using Rudolph Autopol III polarimeter (U.S.A). Column chromatography was performed with silica gel (Marine Chemical Industry Factory, Qingdao, P.R. China), and Macroporous resin D101 (Shandong Lukang Pharmaceutical Co., Ltd.). TLC was preformed with silica gel GF254 (Marine Chemical Industry Factory, Qingdao, China), and developed by spraying with $10 \% \mathrm{H}_{2} \mathrm{SO}_{4}$ followed by heating.

\section{Plant material}

The roots of Calotropis gigantea used in this research were collected from Eman Village of Danzhou County, Hainan Province, P. R. China, in December 2006, and authenticated by Prof. ZhuNian Wang of the Institute of Tropical Crops Genetic Resources, Chinese Academy of Tropical Agricultural Sciences. The voucher specimen (No 20061201) was deposited at the Institute of Tropical Crops Genetic Resources, Chinese Academy of Tropical Agricultural Sciences.

\section{Extraction and isolation}

The roots $(26.7 \mathrm{~kg})$ of Calotropis gigantea were extracted three times with $95 \%$ ethanol at room temperature. Following filtration, the combined ethanol extract was evaporated to dryness under reduced pressure to give a crude extract. The crude ethanol extract was suspended in water $(6.0 \mathrm{~L})$ and successively partitioned with petroleum ether to give Petro-soluble fraction $(236.1 \mathrm{~g})$ and an aqueous residue. Then the aqueous residue was concentrated and applied to a D-101 resin column, eluting with $\mathrm{H}_{2} \mathrm{O}$ and $\mathrm{MeOH}$, successively, the $\mathrm{MeOH}$ eluent was collected and evaporated under reduced pressure to afford the "MeOH fraction" (yield $256.1 \mathrm{~g}$ ). The $\mathrm{MeOH}$ fraction was subjected to vacuum liquid chromatography (VLC) over silica gel, eluting with gradient elution $\mathrm{CHCl}_{3}-\mathrm{MeOH}(100: 0,50: 1,25: 1$, 10:1, 5:1, 2:1, MeOH) to afford seven fractions (Fr.1-Fr.7). Fr.1 (56.3 g) was subjected to further column chromatography over silica gel, with petroleum ether-acetone (6:4) as eluent, to afford compound 1 (32 mg). Fr.4 (20.3 g) was subjected to column chromatography over silica gel, eluting with gradient elution $\mathrm{CHCl}_{3}-\mathrm{MeOH}$ to afford $2(35 \mathrm{mg})$.

Calotropone (1): Yellow gum, $[\alpha]_{\mathrm{D}}^{21}-89.7^{\circ}$ (c 0.26, MeOH); HR-ESI-MS: $m / z[\mathrm{M}+\mathrm{Na}]^{+} 491.2409($ calcd. For $\left.\mathrm{C}_{28} \mathrm{H}_{36} \mathrm{O}_{6} \mathrm{Na}, 491.2404\right)$; $\operatorname{IRv} v_{\max }^{\mathrm{KBr}}\left(\mathrm{cm}^{-1}\right)$ : 3431, 2918, 2849, 1712, 1629, 1463, 1275, 1110 ; $\mathrm{UV}_{\max } \mathrm{nm}\left(\mathrm{CHCl}_{3}\right): 241,267,284 ;{ }^{1} \mathrm{H}-\mathrm{NMR}\left(400 \mathrm{MHz}, \mathrm{CDCl}_{3}\right),{ }^{13} \mathrm{C}-\mathrm{NMR}\left(100 \mathrm{MHz}, \mathrm{CDCl}_{3}\right)$ : Table 1.

Gofruside (2) $[15,16]: \mathrm{C}_{29} \mathrm{H}_{40} \mathrm{O}_{9}$, Colorless needles; m.p. $165-167{ }^{\circ} \mathrm{C}$; IR (KBr) $\lambda_{\max }\left(\mathrm{cm}^{-1}\right): 3437$, 2937, 1738; FAB-MS (neg.) $m / z 535[\mathrm{M}-\mathrm{H}]^{-}$; ${ }^{1} \mathrm{H}-\mathrm{NMR}\left(400 \mathrm{~Hz}, \mathrm{CD}_{3} \mathrm{OD}\right): \delta 5.88(1 \mathrm{H}, b r \mathrm{~s}, \mathrm{H}-22)$, 5.02, 4.89 (each 1H, d, $J=18.3 \mathrm{~Hz}, \mathrm{H}-21), 4.70$ (1H, d, $J=7.9 \mathrm{~Hz}, \mathrm{H}-1$ '), 3.69 (1H, m, H-3), $3.65(1 \mathrm{H}$, m, H-5'), 3.29 (1H, brs, H-3'), 3.23 (1H, dd, $J=2.5,7.7$ Hz, H-2'), 3.14 (1H, dd, $J=1.8,9.4$ Hz, H-4'), 
$1.20\left(3 \mathrm{H}, \mathrm{d}, J=6.0 \mathrm{~Hz}, \mathrm{H}-6\right.$ '), 0.91 (3H, s, H-18); ${ }^{13} \mathrm{C}-\mathrm{NMR}\left(100 \mathrm{MHz}, \mathrm{CD}_{3} \mathrm{OD}\right): \delta 32.1(\mathrm{C}-1), 30.2$ (C-2), 78.7 (C-3), 37.0 (C-4), 45.1 (C-5), 30.0 (C-6), 28.6 (C-7), 43.8 (C-8), 51.9 (C-9), 52.8 (C-10), 22.9 (C-11), 40.6 (C-12), 50.9 (C-13), 86.1 (C-14), 32.8 (C-15), 27.9 (C-16), 52.0 (C-17), 16.3 (C-18), 210.4 (C-19), 178.3 (C-20), 75.3 (C-21), 117.9 (C-22), 177.2 (C-23), 99.9 (C-1'), 72.4 (C-2'), 72.9 (C3'), 74.3 (C-4'), 70.5 (C-5'), 18.2 (C-6').

\section{Cytotoxicity bioassay}

Compounds 1 and 2 were examined for their cytotoxic activity against chronic myelogenous leukemia K562 and human gastric cancer SGC-7901 cell lines. Cancer cells were incubated for 3 days at $37{ }^{\circ} \mathrm{C}$ in the presence of various concentrations of compounds from DMSO-diluted stock solutions. The growth inhibitory property was determined using 3-(4,5-dimethylthiazol-2-yl)-2,5-diphenyltetrazolium bromide (MTT) assay as described by Mosmann [14].

\section{Acknowledgements}

This research was financially supported by National Basic Research Program of China (2007CB116306) and National Programs for Science and Technology development of China (2007B127B00).

\section{References and Notes}

1. Delectis Florae Reipublicae Popularis Sinicae Academiae Sinicae Edita: Flora Reipublicae Popularis Sinicae, Tomus 63; Science Press: Beijing, P.R. China, 1977; pp. 384-386.

2. Mueen Ahmed, K.K.; Rana, A.C.; Dixit, V.K. Calotropis species (Ascelpediaceae)- A comprehensive review. Pharm. Mag. 2005, 1, 48-52.

3. Singh, B.; Rastogi, R.P. Structure of asclepin and some observations on the NMR spectra of Calotropis glycosides. Phytochemistry 1972, 11, 757-762.

4. Lhinhatrakool, T.; Sutthivaiyakit, S. 19-Nor- and 18,20-Epoxy-cardenolides from the leaves of Calotropis gigantea. J. Nat. Prod. 2006, 69, 1249-1251.

5. Kiuchi, F.; Fukao, Y.; Maruyama, T.; Obata, T. Cytotoxic principles of a Bangladeshi crude drug, Akond Mul (Roots of Calotropis gigantea L.). Chem. Pharm. Bull. 1998, 46, 528-530.

6. Sen, S.; Sahu, N.P.; Mahato, S.B. Flavonol glycosides from Calotropis gigantea. Phytochemistry 1992, 31, 2919-2921.

7. Anjaneyulu, V.; Ramachandra Row, L. The triterpenes of Calotropis gigatea Linn. Curr. Sci. 1968, 6, 156-157.

8. Thakur, S.; Das, P.; Itoh, T.; Imai, K.; Matsumoto, T. Latex extractables of Calotropis gigantea. Phytochemistry 1984, 23, 2085-2087.

9. Bhutani, K.K.; Gupta, D.K.; Kapil, R.S. Occurrence of D/E trans stereochemistry isoreric to ursane (cis) series in a new pentacyclic triterpene from Calotropis procera. Tetrahedron Lett. 1992, 33, 7593-7596. 
10. Ali, M.; Gupta, J. New pentacyclic triterpenic esters from the roots of Calotropis procera. Indian J. Chem. 1999, 38B, 877-881.

11. Kitagawa, I.; Zhang, R.; Park, J.D.; Baek, N.I.; Takeda, Y.; Yoshikawa, M.; Shibuya, H. Indonesian medicinal plants. I. Chemical structures of calotroposides $A$ and B, two new oxypregnane-oligoglycosides from the root of Calotropis gigantea (Asclepiadaceae). Chem. Pharm. Bull. 1992, 40, 2007-2013.

12. Shibuya, H.; Zhang, R.; Park, J.D.; Baek, N.I.; Takeda, Y.; Yoshikawa, M.; Kitagawa, I. Indonesian medicinal Plants. V. Chemical structures of calotroposides C, D, E, F, and G, five additional new oxypregnane-oligoglycosides from the roots of Calotropis gigantea (Asclepiadaceae). Chem. Pharm. Bull. 1992, 40, 2647-2653.

13. Pari, K.; Rao, P.J.; Devakumar, C.; Rastogi, J.N. A novel insect antifeedant nonprotein amino acid from Calotropis gigantea. J. Nat. Prod. 1998, 61, 102-104.

14. Mosmann, T. Rapid colorimetric assay for cellular growth and survival: application to proliferation and cytotoxicity assays. J. Immunol. Meth. 1983, 65, 55-63.

15. Elgamal, M.H.A.; Hanna, A.G.; Morsy, N.A.M.; Duddeck, H.; Simon, A.; Gati, T.; Toth, G. Complete ${ }^{1} \mathrm{H}$ and ${ }^{13} \mathrm{C}$ signal assignments of $5 \alpha$-cardenolides isolated from Calotropis procera $\mathrm{R}$. BR. J. Mol. Struct. 1999, 477, 201-208.

16. Pauli, G.F.; Matthiesen, U.; Fronczek, F.R. Sulfates as novel steroid metabolites in higher plants. Phytochem. 1999, 52, 1075-1084.

Sample Availability: Samples of the compounds are available from the co-author Hao-fu Dai (hfdai@yahoo.cn).

(C) 2008 by the authors; licensee Molecular Diversity Preservation International, Basel, Switzerland. This article is an open-access article distributed under the terms and conditions of the Creative Commons Attribution license (http://creativecommons.org/licenses/by/3.0/). 